\title{
White Australia, Black Bodies: the use of Aboriginal bodies and artefacts in Australian public discourses
}

\author{
Danielle Brazier
}

University of Technology Sydney, Faculty of Arts and Social Sciences, PO Box 123, Ultimo NSW 2017, Australia. danielle.c.brazier@student.uts.edu.au

DOI: https://doi.org/10.5130/nesais.v4i1.1515

\begin{abstract}
Indigenous bodies, artefacts and material cultures have largely been represented in the public sphere in ways that reflect and reinforce colonialist understandings of Aboriginality. This essay examines how discourses which position European whiteness in a place of primacy in direct contrast with an Indigenous 'other' continue to prevail in the contexts of museums, the art world and the tourism industry.
\end{abstract}

Keywords: the colonial gaze; othering; politics of representation

Throughout Australia's (white) history, Aboriginal bodies, artefacts and material culture have been deployed extensively in the service of colonialism. From first contact, Europeans constructed the Aboriginal body in ways that allowed them to mitigate and reconcile the ambivalence and contradictions of the colonial project (Bhabha, cited in Morris 1992). In constructing Aboriginal people as primitive, they could justify the destruction, dispossession, discrimination, degradation and genocide they inflicted on them (Lattas, cited in Morris 1992, p. 73). The study of representation is therefore important because "representation itself...[is] a constitutive form of violence, and violence is itself mediated and constituted by representation" (Morris 1992, p. 72). While there is a plurality of colonial discourses of Aboriginality, the political-ideological intention behind them "allows them to be correlated as a congruent system of representation" (Bhabha, cited in Morris 1992, p. 74), one that delimited accepted constructions of Aboriginality. This will be demonstrated first through analysis of the colonisers' use of and control over Aboriginal bodies themselves, followed by representations of Aboriginal bodies, artefacts and material culture in the contexts of museums, the art world, and tourism. In relation to both museums and art, change over time is shown, as other representations begin to challenge those of the dominant colonial discourses.

In colonial environments, representations of the Other were a powerful tool through which Europeans could define the Self. By constructing Aboriginality (and other 'races') as all that was oppositional to themselves, Europeans were able to equate whiteness with humanness, thus universalising the white, Cartesian male and his Enlightenment methods of knowledge production (Moreton-Robinson 2004). Having positioned Indigenous people as "the ultimate embodiment of the visual culture....[while] the 
white intellectual $[\mathrm{w}]$ as the ultimate embodiment of the superior power of words" (Lattas, cited in Moreton-Robinson 2004, p. 84), this 'knowledge' was then enshrined in supposedly value-neutral scientific fields (Moreton-Robinson 2004, p. 83). Through both explicit social Darwinist ideologies and the implicit naturalisation of the European Self, Aboriginal people were constructed as a primordial, primitive Other of dubious humanity (Lattas, cited in Morris 1992, p. 73), which was reflected and reinforced in representations of them as "treacherous, lazy...childish, cunning, dirty, ignoble, noble...backward, unscrupulous, untrustworthy and savage" (Moreton-Robinson 2004, p. 76). Thus, as Langton writes of settler culture:

The most dense relationship is not between actual people, but between white Australians and the symbols created by their predecessors. They relate to...the constant stereotyping iconising and mythologising of Aboriginal people by white people. (Langton, cited in Healy 2008, p. 6)

It is in this context that Aboriginality must be understood. Firstly, the very concept of 'Aborigines' or 'the Aboriginal' is a colonial construct that is constituted by the presence of the non-Aboriginal, which forces many diverse and distinct linguistic and cultural groups into a single whole to adhere to the binary understandings of identity described above (Reynolds 2005, pp. 9-10). Aboriginality should be regarded a socially and interculturally mediated product. For Johnson, there is a distinction between private Aboriginality, which is "defined and redefined by those who are descended from, identify with and are recognised by the Aboriginal community", and public Aboriginality, which is the essentialised understanding that is institutionalised in public entities such as the government, media, church and academia (Johnson 1986, cited in Waitt 1999, p. 147). Langton also makes a similar distinction between the creation of Aboriginality through the stereotyping and mythologising by nonAboriginal people outside of contact zones with Aboriginal people, and that which occurs in dialogic constructions between Aboriginal and non-Aboriginal people and in the interaction of Aboriginal people with each other within Aboriginal spaces (Langton 1994, cited in Waitt 1999, p. 147). In investigating the ways in which Aboriginal bodies and material culture have been constructed and used by white Australian society, it is 'public' or 'mythologised' Aboriginality that primarily concerns us, although —in the post-colonial era — dialogic constructions also play an increasingly important role.

The mutually constitutive relationship between Aboriginality and whiteness has had far-reaching effects, the most tangible of which can be seen in the classification and pathologisation of the Aboriginal body, which was used to justify the violence, dispossession, discrimination and removal of children by the Australian colonial project. At the time of Australia's colonisation, Europeans subscribed to a biological determinism that "claimed that the character and social capabilities of any group were determined through its biological features" (Gillen \& Ghosh 2007, p. 169), forming a hierarchical 'Great Chain of Being' that placed Europeans as the most evolved and advanced humans, and African and Aboriginal people as the least (Reynolds 2005, pp. 68-69). These Linnean classifications were borne out in spurious pseudosciences such as phrenology, the measuring of skulls to prove the intellectual inferiority of non-European races (Reynolds 2005, pp. 69-71). To this end, Aboriginal skeletons were sent to scientists, museums and academic institutions, both in Australia and overseas. In his study of the Queensland frontier, Turnbull highlights that these were not just stolen from sacred burial places, but that the victims of frontier violence were also often mutilated after their 
death to provide such 'specimens' (Turnbull 2008). The institutions to which these were sentincluding the Australian and British Museums - were complicit in these practices, and "scientists and museum curators had few qualms about being knowing beneficiaries of the violence and killings" (Turnbull 2008, p. 4). Phrenological examinations were also conducted on live 'subjects', such as in a missionary's account of a visiting German anatomist who, after measuring the local population's skulls, refused to believe that Aboriginal children could attend school with good results, play in a band or operate a steam engine, despite the missionary offering to show him all three (Turnbull 2008, pp. 67). Such examples reinforce Moreton-Robinson's assertion about the privileging of white 'scientific knowledge' in Western epistemology (Moreton-Robinson 2004).

Sexual relationships, primarily between white men and Aboriginal women, began shortly after first contact, varying from permanent partnerships to rape and coercion (Reynolds 2005, p. 102). The mixed-race children that resulted "presented White Australia with a social, political and an intellectual problem" in the way that they defied the clear-cut racial groupings and identities with attendant evolutionary hierarchy around which the colonial project was built (Reynolds 2005, p. 113). To prevent 'whiteness' from being blurred or diluted, governments came up with elaborate systems of classifications that determined someone's level of Aboriginality (Reynolds 2005, p. 113), with McCorquodale identifying 67 such official categories (McCorquodale 1983, cited in Waitt 1999, p. 147). However, as mixed-race children became more visibly white through generations of "miscegenation", concern over whether they should grow up in Aboriginal communities increased (Reynolds 2005, p. 103). This lead to policies of child removal, as mixed children, who were thought to be more intelligent than their full-blood counterparts, were taken from their families and communities and placed in educational and training institutions (Reynolds 2005, p. 217). The bodies of Aboriginal girls were of particular cause for concern because of their reproductive abilities, which could be controlled by their placement in institutions and workplaces - although many subsequently faced sexual assault and rape in these environments (Reynolds 2005). As Liebermann writes, "control over sexuality and reproduction was at the core of defining colonial privilege and its boundaries" (Liebermann, cited in Gillen and Ghosh, p. 188), and nowhere is this more evident than in ways that Aboriginal women's bodies were regarded as dangerous - yet available for the use of white men - and regulated accordingly.

Museums have been one of the primary sites through which Aboriginal bodies and material culture have been interpreted. Once again, the museum is a specific cultural form that, although exported across the world and often regarded as objective and scientific, reflects Enlightenment Europe's knowledge production and values. Thus, art and artefacts from non-Indo-European cultures have traditionally been represented as ethnological or anthropological curiosities, while the collection and display of human remains supported the racialised science described above (Healy 2008, p. 133). This leaves Aboriginal Australians constructed as permanent "Stone Age primitives...outside of history, fixed in another time to both modernity and the present" (Healy 2008, p. 46). In short, the ways in which Aboriginal artefacts are discursively situated within museums also potentially presents Aboriginal people themselves as subjects for display, as 'noble savages' with an ancient and unchanging culture (Healy 2008). Defining Aboriginality through material culture as oppositional to modernity, as museums traditionally have, creates a conception of Aboriginal authenticity that delegitimises urban Aboriginal people along with others who do not fit this mould (LambertPennington 2007, p. 315). 
However, museums are increasingly coming to terms with their position as sites of power that have constructed and reproduced potentially problematic representations of Aboriginality and taken part in harmful colonial practices. Many Australian museums are collaborating with Aboriginal and Torres Strait Islanders peoples to review the handling, care and representation of Indigenous material culture within their collections (Lambert-Pennington 2007, p. 315) in what can be seen as an example of Langton's dialogic form of Aboriginality (Langton 1994, cited in Waitt 1999, p. 147). There is a similar move towards the repatriation of human remains from museum and academic collections, and 1,150 sets of remains have been returned to country from overseas museums since 1990 (Koori Mail 486, cited in Korff 2017). Despite these steps forward, over 1,000 more remain outside Australia (Koori Mail 486, cited in Korff 2017), and 10,000 in Australian museums (Sydney Morning Herald, cited in Korff 2017). Thus, as Turnbull has observed, "the aims and practices of nineteenth century racial science continue to be a dark, and in many ways unresolved legacy of...[the] colonial past" (Turnbull 2008, p. 3).

With Aboriginal art and artefacts historically being placed together in the museum to display the culture of the primitive Other, the association between the art world and Aboriginal material culture is not a long one. When Mountford donated artworks collected during the 1948 American-Australian Scientific Expedition to Arnhem Land to state art galleries, prominent anthropologists criticised the move, making the statement that Aboriginal cultural production "could neither be enjoyed, nor exist, without rigorous ethnographic study" (Jones n.d.). The placement of these works within a gallery context pioneered the recognition of Aboriginal and Torres Strait Islander art as contemporary cultural artefacts (Jones n.d.), thus beginning to free Aboriginal material culture and, by extension, Aboriginal people, from the time-warp of the museum. However, contemporary Aboriginal 'high art' is conventionally traced back to the Papunya Tula dot paintings of the Western Desert that were first popularised in the late 1970s. Although 'modern' Aboriginal art pre-dates Papunya and encompasses more than its style of dot painting, the Papunya style constituted both "a new mode through which Indigenous people were recognised by White Australia" and, eventually, "the public face of Australia for the world" (Healy 2008, p. 71). In the decades since, its dots and concentric circles have come to symbolise both Aboriginal and Australian art, and have adorned everything from touristic tea towels to QANTAS planes and uniforms. Despite, or perhaps because of this trivialisation, modern Aboriginal art is now considered to be "most widespread and perhaps significant manifestation of Indigenous culture in the public sphere" (Healy 2008, p. 66). It is presented not just in art galleriesincluding in blockbuster shows at the National Gallery of Australia-but also in public institutions such as Parliament, international auction houses, business and private collections (Healy 2008, p. 6667). The re-conception of Aboriginal art as 'real' art helped to weaken colonial discourses of primitivity that were embodied in museums. However, the popularity of Papunya art has led to it becoming symbolic not just of the Western Desert community, but of Aboriginal people and culture in general, and this may be leveraged discursively to prescribe what art forms are authentically or acceptably Aboriginal.

Running parallel to Aboriginal high art is the cultural production of Aboriginalia. Healy defines the concept as a "disparate body of Indigenous-derived images and objects made by non-Indigenous artists" (Healy 2008, p. 80), while to Franklin it refers to "decorative objects depicting Aboriginal people and/or cultural and motifs" and is primarily "designed for, sold to and produced by nonAboriginal Australians" (Franklin 2010, p. 203). It thus includes both what is referred to as 
'Aboriginal kitsch', as well as Aboriginal-inspired high art, both of which first became cultural phenomena in the aftermath of the Queen's 1954 visit, when Aboriginal motifs were used for banners and other paraphernalia, and the ballet Corroboree was performed (Franklin 2010, pp. 200-1). These products typically positioned Aboriginal people once more as primitive, situating their material culture - boomerangs, rock art motifs, didgeridoos - as part of a Stone Age past, even as it reproduces them as part of contemporary Australian culture (Franklin 2010, p. 203). Thomas explains this apparent contradiction as a process through which settler culture is localised and a narrative of national progress is established:

[By] forging national narratives that situate Indigenous people firmly in the past... white settlers are identified with what is new and flourishing and promising. In this way, the potential paradox arising from the use of natives of to affirm the native status of settlers [such as through Aboriginalia] is mediated by a narrative of succession: future is to past as settler is to savages. (Thomas, cited in Healy 2008, p. 83)

Not only is this applicable to the broader representations of Aboriginality that have been discussed, it also speaks to the ambivalence and instability at the heart of the colonial project that requires the Indigenous Other to be located in "a fixed reality which is yet entirely knowable and visible" in order to reconcile its essential internal contradiction (Bhabha, cited in Morris 1992).

According to Franklin, it was the popularity of Aboriginalia and Aboriginal high art that prompted the tourism industry to utilise representations of Aboriginal people and culture in external nation-branding exercises (Franklin 2010, p. 204). Regardless of whether or not this is true, the use of Aboriginal bodies and imagery in tourism form influential representations of Aboriginality. In these discursive interventions, the typical image used is that of "semi-naked bodies performing dance or traditional ritual” (Pomering 2013, p. 70). In the famous 'Where the bloody hell are you?' campaign, Aboriginal dancers are pictured performing a traditional dance against stereotypical Outback scenery, before one turns and says "and we've been practicing for 40,000 years", which, along with other preparations Australians have made, such as "getting the roos off the green", leads into the question of "where the bloody hell are you?", in which 'you' is the international tourist (Pomering 2013, p. 73). This was followed by a tie-in campaign with Baz Luhrmann's film Australia, which saw young Aboriginal actor Brandon Walters, dressed in only a loincloth, enter the apartment of a stressed female executive, and encourage her to "come walkabout" to Australia. As Pomering (2013, p. 73) writes, these are once again "harking back to ideas of the noble savage", positioning Aboriginal Australians as a magical people outside of time, the ramifications of which have already been discussed.

Overall, Aboriginal bodies, artefacts and material culture have primarily been used in the public sphere in ways that reflect and reinforce colonialist representations and understandings. These have their origins in binary constructions of the European Self/Indigenous Other that underpinned the colonial project, as well as the interrelated justifications provided by spurious racial sciences and the positioning of Europeanness and the associated modes of social and cultural production as universal. While cultural change is undoubtedly lessening the ability of these discourses to be used in certain contexts such as in museums and the art world, they continue to be a powerful force in modern Australia, as is shown through their mobilisation in tourism campaigns. As Morris writes in his exploration of the frontier, such representations of Aboriginality have real world consequences, 
because they "impose a truth which attributes to Aborigines an essential being and, in effect, denies the social reality of their existence" (Morris 1992, p. 87).

\section{References}

Franklin, A. 2010, 'Aboriginalia: Souvenir Wares and the 'Aboriginalization' of Australian Identity', Tourist Studies, vol. 10, no. 3, pp. 195-208. https://doi.org/10.1177/1468797611407751

Gillen, P. \& Ghosh, D. 2005, Colonialism \& Modernity, University of New South Wales Press, Sydney.

Healy, C. 2008, Forgetting Aborigines, University of New South Wales Press, Sydney Jones, J. n.d., Mountford Gifts: Work from the American-Australian Scientific Expedition to Arnhem Land 1948, Art Gallery of New South Wales, Art Gallery of New South Wales, Sydney.

Korff, J. 2017, Aboriginal remains repatriation, Creative Spirits, viewed 17 June 2018, $<$ https://www.creativespirits.info/aboriginalculture/people/aboriginal-remains-repatriation>.

Lambert-Pennington, K. 2007, 'What Remains? Reconciling Repatriation, Aboriginal Culture, Representation and the Past', Oceania, vol. 77, pp. 313-333. https://doi.org/10.1002/j.18344461.2007.tb00019.x

Moreton-Robinson, A. 2004, 'Whiteness, epistemiology and Indigenous representation' in MoretonRobinson, A. (ed.), Whitening Race: Essays in social and cultural criticism, Aboriginal Studies Press, Canberra, pp. 75-88.

Morris, B. 1992, 'Frontier colonialism as a culture of terror', Journal of Australian Studies, vol. 16, no. 35, pp. 72-87. https://doi.org/10.1080/14443059209387119

Pomering, A. 2013, 'Indigenous Identity in the Nation Brand: Tension and Inconsistency in a Nation's Tourism Advertising Campaigns', Corporate Reputation Review, vol. 16, no. 1, pp. 66-79. https://doi.org/10.1057/crr.2012.26

Reynolds, H. 2005, Nowhere People, Penguin Books, Camberwell, Victoria.

Turnbull, P. 2008, 'Theft in the Name of Science', Griffith Review, Edition 21, viewed 16 June 2018, $<$ https://griffithreview.com/articles/theft-in-the-name-of-science/>.

Waitt, G. 1999, 'Naturalizing the 'primitive': A critique of marketing Australia's indigenous peoples as 'hunter-gathers', Tourism Geographies, vol. 1, no. 2, pp. 142-143.

https://doi.org/10.1080/14616689908721306 